\title{
Yo tengo mono
}

\section{I'm at addict}

\section{Sr. Director}

Me explico, durante mi vida profesional he remitido a Revistas Nacionales e Internacionales del ámbito de la Cirugía Oral y Maxilofacial, de Cuidados Intensivos y de Anestesiología, Reanimación y Tratamiento del Dolor preferentemente, no pocos trabajos, la mayoría referentes a técnicas y/o procedimientos personales, para aportar posibles avances o mejorar lo conocido, habiendo desestimado, el publicar casos clínicos más o menos extraordinarios, pese a haber visto y tratado no pocos, con resultados tal vez más que aceptables.

Pues bien, además del trabajo que todo esto exige y que las ideas no surgen así como así y, que cuando esto ocurre, tienes que elaborarlas para su correspondiente desarrollo y aplicación salvando mil dificultades (hasta el punto que a veces piensas, Dios mío que no se me ocurra nada más) seguidamente hay que intentar publicarlo en Revistas de tu ambiente profesional.

A mi, al menos, me sucede que cuando por fin has conseguido elaborar el Artículo, para su posible publicación, ateniéndote a la "tiranía", no siempre muy precisa y, tal vez, en cierta manera más o menos ininteligibles (porque cada Revista tiene su idiosincrasia de las normas de publicación), resulta que te las devuelven (en los mejores casos) para que corrijas el texto, la traducción si es el caso, las fotos, los dibujos, la bibliografía, etc. Pero, no lo voy a negar: he recibido y sigo recibiendo, misivas de las distintos Editores, con el siguiente contenido, más o menos: "No aceptado para su publicación en nuestra Revista... Agradeciéndole, eso sí, el que la haya considerado para su publicación y esperando seguir contando con su participación para otras posibles publicaciones, etc.".

Por todo ello, quiero intentar aportar una vez más y, con quizá cierta originalidad, lo que a mí me pasa, por si lo mismo o parecido, le puede ocurrir a otros y, todo ello, con la intención de que se humanice el procedimiento de selección de trabajos, con arreglo a las diversas etapas que he podido determinar por mi experiencia a lo largo de tantos años y que los afectados vean que no sólo les pasa a ellos y, así, soportar y salir mejor del trauma que me atrevo a denominar provisionalmente Síndrome del Articulista, que precisará probablemente de mas reflexiones y aporte de síntomas todavía sin determinar...

Etapa 1 o de la llusión: Mandas, por fin, después de no pocos esfuerzos de todo tipo (para qué voy a enumerarlos), tu manuscrito (ciber-escrito, mejor dicho), más o menos "impecable" (al menos para ti y para los que te rodean que te dicen: "Vamos, que está muy bien", sobre todo hoy día, con los medios informáticos con que contamos y que parece que todos sabemos manejar con
Mr. Director

I'd like to explain myself; during my professional life I have submitted many articles to National and International Magazines within the scope of Oral and Maxillofacial Surgery, Intensive Care, Anesthesiology, Reanimation and Treatment of pain. The majority of these projects refer to techniques and/or personal procedures that could contribute to advancement or improvement of what we know. Although I have seen and treated many somewhat extraordinary clinical cases with acceptable results none of the articles that I have published discussed these cases.

Besides the work that all of this entails and the fact that the ideas do not just appear out of nowhere. When this happens you have to elaborate on them for their corresponding development and use, despite the thousands of difficulties (sometimes you even reach the point where you say, my God please let this be it). Right afterwards you have to try to publish your work in Magazines related to your professional field.

It happens, to me at least, when you finally elaborate the article for the possibility of publication, trusting in the tyranny. Not always important and perhaps in some way more or less unintelligible (because each magazine has its idiosyncrasies in its publication procedures) as a result they send them back to you so you can make corrections in the text, the translation, the photos, the drawings, the bibliography etc. But I am not going to deny it: I have and still receive letters from a few specific editors with more or less the following content: "Not accepted for publication in our magazine... Thank you and hope to remain in contact for your possible participation in future publications etc."

Because of all of this, I want to try to contribute one more time and, with certain originality, what happens to me, in case something the same or similar happens to others. All of this is intended to humanize the selection process according to the diverse phases that I have defined from my experience over many years. I hope that those affected by similar situations see that it doesn't just happen to them. I would like to provide them with support and the ability to get out of the trauma that I dare to name Articlist Syndrome. Which will probably come from my thoughts and additional symptoms that have yet to be determined.

Phase I Excitement: Finally, after all kinds of effort you send your, more or less, impeccable manuscript(at least your 
enorme destreza). Esta etapa sólo de confección del artículo, puede llevarte un par de meses, porque ya se sabe, lo dejas, lo coges, etc.

Etapa II o de la Incertidumbre: Por fin recibes notificación, que el trabajo ha llegado más o menos correctamente a la Redacción, aunque no pocas veces, jfalta algo! Y, claro, les mandas lo que te piden $y$, ahora sí, nueva confirmación de que todo es correcto ( $y$ dentro de ti, se refuerza la situación de la Etapa I), si les adviertes, te contestan habitualmente pronto, de que ya ha llegado todo correctamente (sensación de alivio también). Este período, suele ser relativamente corto.

Etapa III o de la Preocupación llusionada: Puede durar una eternidad, incluso hoy día con tanto adelanto, recuerda la situación, un tanto a lo que parece que pasa en los juzgados, en los que la resolución de tu asunto se retrasa y claro, tú (al menos yo), piensas de todo, que se habrá perdido "el expediente", que el Director de la Revista a lo mejor o lo peor, te tiene manía, que los Revisores tendrán mucho trabajo y, además, que a ver a quién se lo han mandado... y como "vean" que es mío, pues lo rechacen y más si no tienen un poco de sentido del humor...

Etapa IV o de la Hora de la Verdad: Ahora, habitualmente, te llega un e-mail con el resultado de la "sentencia" $y$, enseguida, si el Adjunto te ha llegado (porque puede no haber llegado, o no descargarse, o no abrirse...) de inmediato tienes el veredicto (en mi caso, jhabitualmente desfavorable!), lo que determina, sin duda un impacto emocional, por ahora sin repercusiones neurovegetativas insalvables y que me permiten reaccionar con cierta deportividad y rabia contenida, que transformas poco a poco, en ver, qué uso puedes hacer del rechazo, siempre personal (se diga, lo que se diga), para que no resulte baladí tu esfuerzo (es el momento de pensar: "¡Pues lo voy a mandar a otra Revista!" o similar, porque sigues pensando que lo que tú has mandado no es ¡malo! y has seguido la normativa y es injusto... y ya está).

Hace años, cuando estabas a la espera de un resultado de la Editorial correspondiente y abrías el Buzón de Correos, un día, y otro, y no venía nada, hasta que por fin (y malo), si veías un sobre grande con sellos extranjeros, para que pensaras, ¡me lo han devuelto!... y solía ser verdad (tu sólo querías ver un sobre normal, de los de toda la vida, eso sí, con sellos extranjeros y matasellos de colores, faltaría más).

Etapa $V$ o de alegría infinita: (que ocurre muy ocasionalmente) ¡me lo han aceptado!, le das un beso a la mujer, a las hijas (es mi caso) y tu estima, se eleva a límites indescriptibles (las hormonas buenas se disparan, hacen su efecto y notas una mejora de tu sistema inmunitario, tu autoestima, entre otros...) y idura para siempre!

Etapa VI o de decepción: (la más frecuente), te planteas si debes seguir mandando trabajos o mandarlo todo al cara..., al final, en poco tiempo habitualmente, vuelves a caer en la adicción y mandas otro trabajo, esperando... recuperarte del mono (¿me volverá a pasar?).

\section{Dr. F. Hernández Altemir} Zaragoza. España friends and family tell you "Come on, it's great", especially today with all of the forms of information available, it seems that we all know how to use so skillfully). This stage of merely preparing the article can last a few months because as we all know, you work on it for a while and then you leave it alone for a while, etc.

Phase II Uncertainty: Finally you get the news that your article arrived successfully to the editorial staff, however more often than not, something is missing! Of course, you send them what they ask for and now, new news arrives that everything is correct (and you feel the same way as in phase I) if you watch them they typically answer in a timely manner that everything is fine (sense of relief). This period usually is relatively short.

Phase III Worried Excitement: This phase can last an eternity, even today with so much advance, remember the situation, a portion of what seems to happen in the court room in which the resolution to the problem is pretty clear, you (at least I) think of every possibility: they must have lost the file, the Magazine director has it out for me, the reviewers have a lot of work, or lets see who they sent it to because when they see its mine they'll deny it right away especially if they don't have a sense of humor.

Phase IV the moment of Truth: Now, usually, you will get an e-mail with your "sentence". If the attachment is there (because sometimes it isn't attached, it doesn't download, or it doesn't open) then the verdict is in (in my case usually an unfavorable one!). Which has an emotional impact, for now, without neurovegetative repercussions and I am able to react with a sense of good sportsmanship and controlled rage. This transforms little by little into the quest for how to handle the rejection, always personal (say what they say) so that your effort doesn't seem insignificant (its time to think: Well I'm going to send it to another magazine" because you think what you sent isn't bad! It's just not fair and that's that).

Years ago when you were waiting for a response from an editorial and you opened the mailbox day after day and nothing came. Until finally, you saw a big envelope covered in foreign stamps and you thought "They sent it back!" which was usually the case (but you just wanted a normal envelope with foreign stamps and colorful postmarks, is that to much to ask?).

Phase V Infinite Happiness: (This happens very rarely) I've been accepted! You kiss your wife and, in my case, your daughters and your esteem is soaring at unforeseen heights (good hormones are released and have their positive effect and you notice increased immunity and self esteem among others...) and it lasts forever!

Phase VI Deception: (The most common) You decide whether to continue sending projects or to just say screw it. In the end after a short time, you give into your urge and you send another article, you wait etc. recover from your addiction (will it all start again?). 